\title{
Glycoconjugate Residues Type in Endometrium Aceh Cattle (Bos indicus) During Estrus Cycle
}

\author{
Muhammad Jalaluddin ${ }^{1 *}$, Teguh Budipitojo ${ }^{2}$, Dwi Liliek Kusindarta ${ }^{2}$, Fajar Shodiq \\ Permata ${ }^{3}$, Priyo Sambodo ${ }^{4}$, Hamny Hamny ${ }^{1}$, Sri Wahyuni ${ }^{1}$, Mustafa Sabri ${ }^{1}$, Teuku \\ Reza Ferasyi ${ }^{5}$, Erdiansyah Rahmi ${ }^{6}$, Awaluddin Awaluddin ${ }^{7}$ \\ ${ }^{1}$ Laboratory of Anatomy, Faculty of Veterinary Medicine, Universitas Syiah Kuala, Banda Aceh, Indonesia \\ ${ }^{2}$ Division of Anatomy, Faculty of Veterinary Medicine, Gadjah Mada University, Yogyakarta \\ ${ }^{3}$ Veterinary Anatomy and Histology Laboratory, Faculty of Veterinary Medicine, Brawijaya University, Malang \\ ${ }^{4}$ Veterinary Parasitology Laboratory, Faculty of Animal Husbandry, University of Papua, Manokwari, West Papua \\ ${ }^{5}$ Laboratory of Veterinary Public Health, Faculty of Veterinary Medicine, Universitas Syiah Kuala, Banda Aceh \\ ${ }^{6}$ Laboratory of Histology and Embryology, Faculty of Veterinary Medicine, Universitas Syiah Kuala, Banda Aceh \\ ${ }^{7}$ Laboratory of Pathology, Faculty of Veterinary Medicine, Universitas Syiah Kuala, Banda Aceh \\ *Corresponding author. E-mail: jalal_permai@unsyiah.ac.id
}

\begin{abstract}
The ability of aceh cattle to reproduce in extreme environments is thought to be supported by their reproductive system. This research was conducted to study the reproductive system of Aceh cattle by identifying the types and distribution of glycoconjugates in the endometrium of Aceh cattle at various stages of the estrous cycle. This study used the fifteen pubescent female Acehn cows, the phase of the estrous cycle, and weighing 200-300 kg. Samples were obtained from the slaughterhouse of Banda Aceh City, Aceh Province. The uterus is fixed in Bouin's solution and processed histologically. The uterus is stained with histochemical lectins (Con-A, WGA, RCA, and UEA-I) to detect the type of glycoconjugate. The data obtained are presented in the form of images and analyzed descriptively. The glycoconjugates of D-galactose, L-fucose, D-mannose / D-glucose, and N-acetyl-D-glucosamine can be identified in the endometrium of aceh cattle at various stages of the estrous cycle. The presence of these glycoconjugates is thought to play an important role in the reproductive process that occurs in the endometrium of aceh cattle during the estrous cycle.
\end{abstract}

Keywords: Aceh cattle, glycoconjugate, endometrium, estrous cycle, lectin histochemistry

\section{INTRODUCTION}

Aceh cattle are the germplasm of Aceh Province that has developed and is able to adapt to areas with hot, dry natural conditions, limited food sources and water sources [1,2].

An important factor in efforts to increase the population and preserve the germplasm is to characterize and identify the characteristics of production and reproduction of Aceh cattle. Muntasib and Masy'ud [3] state that the process of saving and protecting biodiversity, both animals and plants, must be supported by studies on the physiological conditions of biodiversity itself. The study of the type and distribution of glycoconjugate in the endometrium of aceh cattle at various stages of the estrous cycle is a useful study to determine the physiological condition of their reproduction.

The female reproductive tract is one of the systems in the animal body that experiences development and morphological changes during pregnancy [4] and the uterus undergoes a series of morphological and physiological changes during the estrous cycle and the reproductive process [5]. During this process, there is also a change in the type of glycoconjugate [4]. The uterine gland is a simple tubular gland that undergoes changes during the estrous cycle $[6,7]$.

Glycoconjugates play an important role in the structure of cells and tissues and the biological processes that occur therein. The distribution of glycoconjugates in cells in a certain area can provide predictions related to 
their possible function at that location [8], glycoconjugates play an important role in cell and tissue structure and the biological processes that occur therein [9].

Based on the statements above, the effort to identify the types and distribution patterns of glycoconjugate re219 $\mathrm{P}$ a $\mathrm{g}$ e sidues in the endometrium of Acehnese cows at various phases of the estrous cycle, it is important to use lectin histochemical methods.

The decline in the Aceh cattle population has received serious attention from various parties, especially the Aceh Provincial government. In order to support efforts to increase the population and conserve Aceh cattle as germplasm in Aceh Province, a study on the reproductive system of aceh cattle is very important.

\section{MATERIALS AND METHODS}

After slaughtered, the uterus is immediately separated from the reproductive tract and put into a fixative, then the tissue is processed for microscopic observation. The area of observation included the cornua uteri, body and cervix $(n=15)$.

Tissue processing is carried out by microtechnics, including fixation, dehydration, clearing, infiltration, embedding, sectioning, and mounting. The procedure for making histological preparations according to Luna's procedure [10].

Lectin staining is used to determine the type and distribution of mucopolysaccharide sugar residues contained in cells/tissues/organs [11]. The type, specificity and dose of lectins used to determine the type of carbohydrate glycoconjugate residues in the endometrium of aceh cattle during the estrous cycle are presented in Table 1.

Table 1. Type, specificity, and dose of lectins

\begin{tabular}{|c|l|l|l|l|}
\hline No. & Lectin Name & $\begin{array}{l}\text { Abbre } \\
- \\
\text { viation }\end{array}$ & Specification & $\begin{array}{l}\text { Dosis } \\
(\mu \mathrm{g} / \mathrm{ml} \\
)\end{array}$ \\
\hline 1. & $\begin{array}{l}\text { Concanavalin } \\
\text { agglutinin }\end{array}$ & Con A & $\begin{array}{l}\alpha-D-M a n, \\
\alpha-D-G l c\end{array}$ & 10 \\
\hline 2. & $\begin{array}{l}\text { Wheat germ } \\
\text { agglutinin }\end{array}$ & WGA & $\begin{array}{l}\beta-G \text {-GNAc, } \\
\text { sialic acid }\end{array}$ & 10 \\
\hline 3. & $\begin{array}{l}\text { Ricinus } \\
\text { communis } \\
\text { agglutinin }\end{array}$ & RCA & $\begin{array}{l}\beta-G a l, \beta- \\
\text { GalNAc }\end{array}$ & 10 \\
\hline 4. & $\begin{array}{l}\text { Ulexeuropae } \\
\text { us agglutinin }\end{array}$ & UEA-I & $\alpha$-L-fucose & 10 \\
\hline
\end{tabular}

Description: Man: mannose, Glc: $\beta$-glucose, GlcNAc: Nacetylglucosamine, Gal: $\beta$-galactose, GalNAc: Nacetylgalactosamine, L-fuk: fucine [7].
The variable that was observed semiquantitative and the intensity of the positive reactivity of the histochemical lectins which was indicated by the presence of a brown color in the tissue. The distribution results and the intensity of the reactions of endometrial cells to several types of lectins were scored subjectively based on the results of lectin visualization in the tissue. The scoring is based on the strength and weakness of the reaction intensity of the stain on the tissue in one field of view. The scores are divided into 4 (four) categories and with negative control, namely:

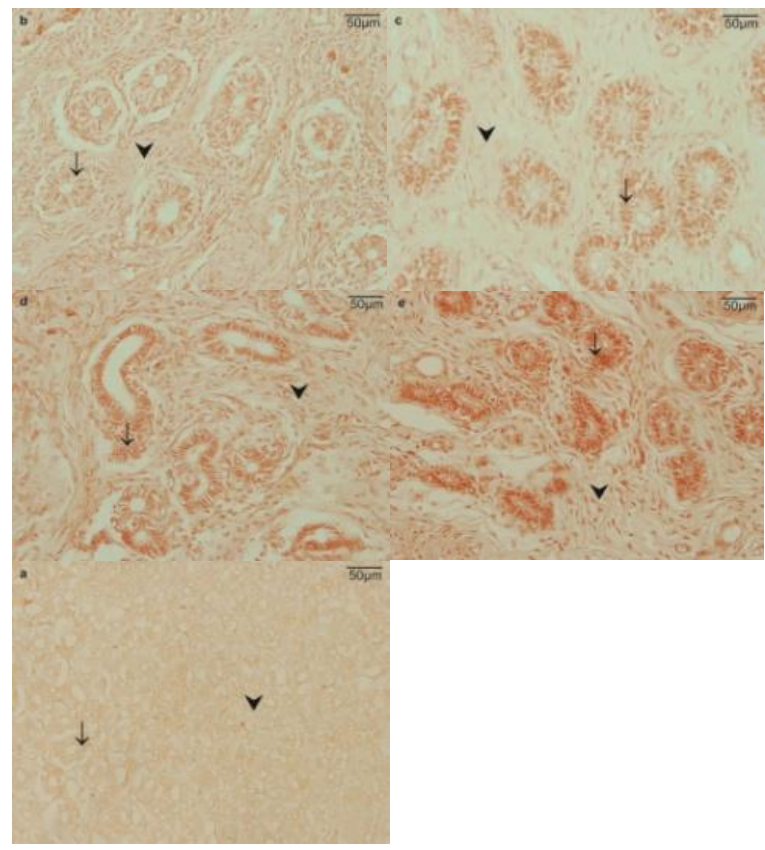

Description:

a. no brown (-) contrast was found on the network $(\downarrow)$ and background ( $\checkmark)$,

b. found a brown contrast with a weak intensity (+) between the tissues $(\downarrow)$ with the background $(\checkmark)$,

c. found a brown color contrast with quite strong intensity (++) between the networks $(\downarrow)$ and background $(\checkmark)$, and

d. brown color contrast found with very strong intensity $(+++)$ between the tissues $(\downarrow)$ and background $(\checkmark)$.

e. Negative control, no brown contrast was found on the tissue $(\downarrow)$ and background $(\checkmark)$

The data obtained are semiquantitative. Semquantitative data as a result of microscopic observations are presented in the form of images, and analyzed descriptively.

\section{RESULTS AND DISCUSSION}

The glycoconjugate reactivity of the endometrium and uterine glands of aceh cattle during the estrous cycle by lectin histochemical staining is presented in Figure 16. 


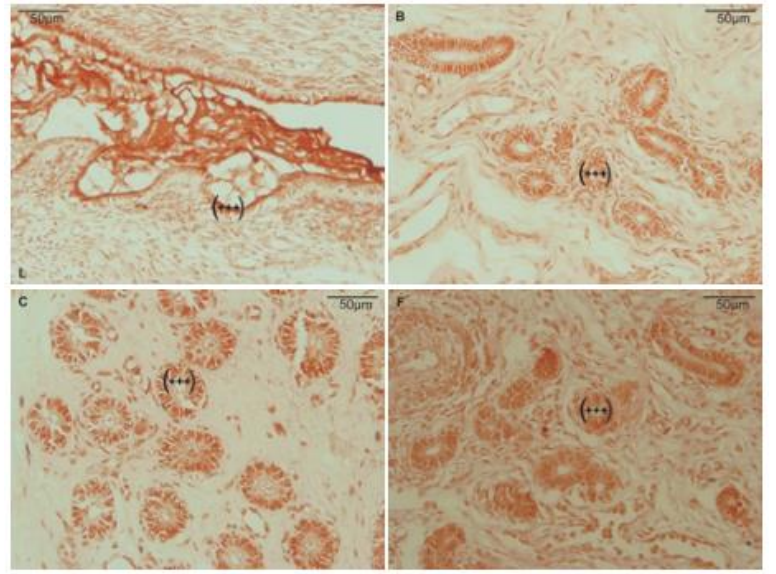

Figure 1 Glycoconjugate reactivity in endometrium and uterine glands of Aceh cattle by histochemical lectin Con-A staining. Lamina mucosal epithelial cells in the cervix have a very strong positive reaction to Con-A lectins in the diestrous phase (Figure L), uterine glandular cells in the corpus have a very strong positive reaction to Con-A lectins in the proestrus phase (Figure $\mathrm{B})$, uterine glandular cells in the cornua. Very strong positive reaction to Con-A lectin in the estrous phase (Figure $\mathrm{C}$ ), and uterine glandular cells in the corpus have a very strong positive reaction to Con-A lectin in the metestrous phase (Figure F). 40x2.5 magnification. Description $=(+++)$ : very strong reactivity.

\subsection{Con-A Lectins}

Con-A lectins indicate the presence of D-manose / Dglucose sugar residues in cells and / or tissues. The ConA lectin has a specific bond with the D-manose / Dglucose glycoconjugate. Wulster-Radcliffe et al. [12] stated that the injection of Con-A in pigs was able to stimulate the mobilization of immune cells, especially $\mathrm{T}$ lymphocytes. In the endometrium of aceh cattle, Con-A lectin reacts very strongly in the corpus uterine gland cells in the proestrus phase. uterine cornua gland cells in the estrous phase, uterine corpus gland cells in the metestrous phase, and uterine cervical epithelial cells in the diestrous phase. The reactivity of the Con-A lectin suggests the activity of the uterine glands and uterine cervical epithelial cells to mobilize immune cells (lymphocytes) to maintain uterine environmental conditions in order to remain safe from invasion of foreign microorganisms.

\subsection{WGA Lectins}

WGA lectins indicate the presence of sugar residue $\mathrm{N}$-acetyl-D-glucosamine ( $\beta$ GlcNac) in cells and / or tissues. Hock and Hollenberg [13] stated that epidermal growth factor receptors contain N-acetyl-D-glucosamine sugar residues, where the WGA lectin itself has a specific bond to the sugar residue. Epidermal growth factor can trigger the regeneration and proliferation of mucosal epithelial cells. Research on aceh cattle shows that in the uterine corpus in the proestrus phase there is a process of proliferation of epithelial cells for regeneration as a result of the shedding of the epithelial layer in the diestrus phase. In addition, the proliferation process in the uterine gland during the metestrous phase is thought to be related to the provision of uterine milk for the embryo / fetus if pregnancy occurs.

This study, which was conducted on non-pregnant Aceh cattle, supported the above allegations by showing a decrease in the reactivity of the WGA lectin at the diestrous stage. This is consistent with the report of Munson et.all [14] that the reactivity of the WGA lectin in the endometrium of cows with gestation over 80 days (diestrous phase) shows a very strong positive reaction.
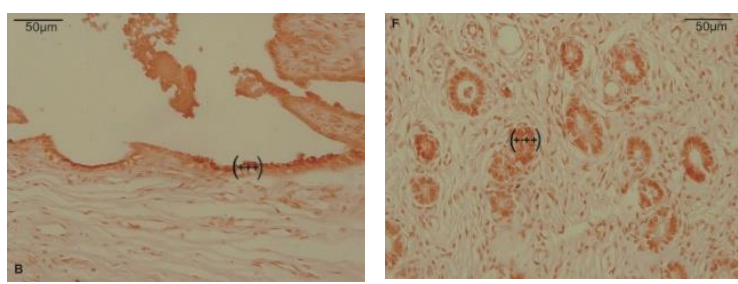

Figure 2 Glycoconjugate reactivity in endometrium and uterine glands of Aceh cattle by histochemical lectin WGA staining. Lamina mucosal epithelial cells in the corpus have a very strong positive reaction to WGA lectins in the proestrus phase (Figure B), and uterine glandular cells in the corpus have a very strong positive reaction to WGA lectins in the metestrous phase. 40x2.5 magnification. Description $=(+++)$ : very strong reactivity

\subsection{RCA Lectins}

RCA lectins indicate the presence of D-galactose $(\beta$ Gal) sugar residue in cells and / or tissues. Horvat [15] stated that the galactose-binding lectins can be used as a sign of pregnancy in animals. RCA lectin reactivity was seen very strongly in non-pregnant animals, but its reactivity will disappear during pregnancy, so that Dgalactose is thought to function as an identifier for the presence of an embryo at the onset of pregnancy. In addition, D-galactose is part of the galactosyltransferase enzyme associated with the fertilization process [16], in this case it plays a role in the capacitation process of spermatozoa.

The reactivity of RCA lectins in the uterine corpus and uterine cornua of aceh cattle in the proestrus and estrous phases indicates the preparatory activity of the uterus against the presence of the embryo, while the reactivity of RCA lectins in the uterine cervix and uterine corpus in the estrous phase is thought to have a relationship with the spermatozoa capacitation process. 


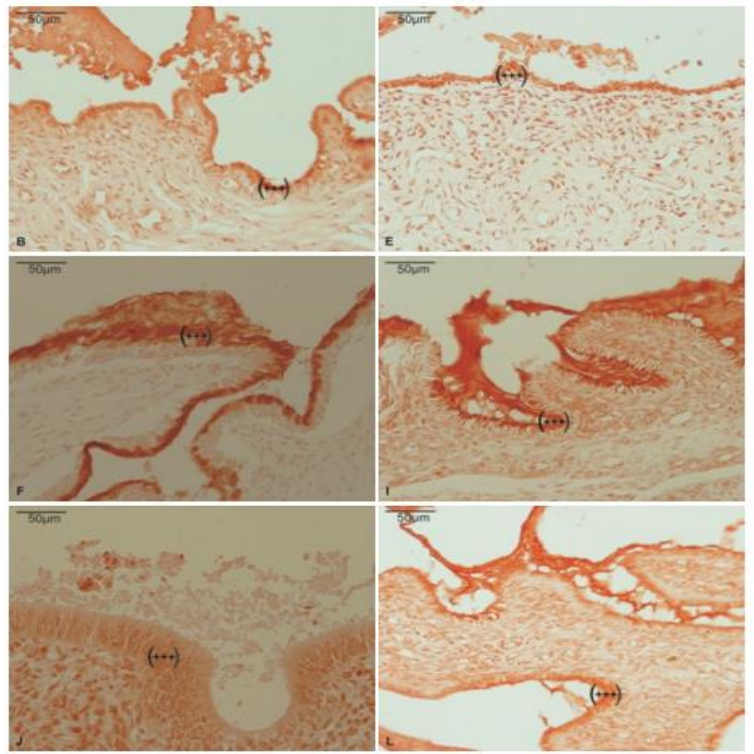

Figure 3 Glycoconjugate reactivity in the uterine endometrium of aceh cattle with histochemical lectin RCA staining. Mucosal epithelial lamina cells in the corpus react very strongly to RCA lectins in the proestrus phase (Figure B), mucosal epithelial lamina cells in the corpus (Figure E) and in the cervix (Figure F) react very strongly to RCA lectins in the estrous phase, cells The mucosal epithelial laminae in the cervix are very strong against RCA lectins in the metestrous phase (Figure I), and the mucosal epithelial laminae cells in the cornua (Figure J) and cervix (Figure L) react very strongly to RCA lectins in the diestrous phase. 40x2.5 magnification. Description $=(+++)$ : very strong reactivity.

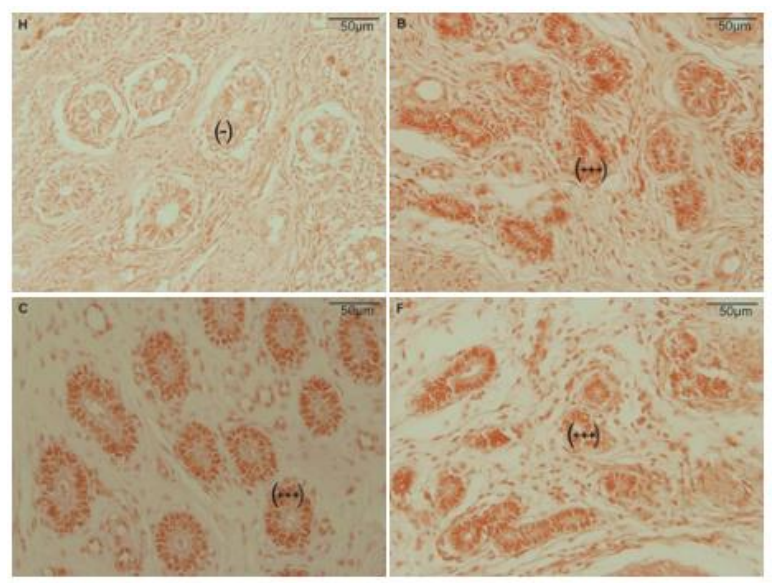

Figure 4 Glycoconjugate reactivity in the uterine glands of aceh cattle with histochemical lectin RCA staining. Uterine gland cells in the corpus react very strongly to RCA lectins (Figure B) in the proestrus phase, uterine gland cells in the cornua have a very strong positive reaction to RCA lectins in the estrous phase (Figure C), and uterine glandular cells in the corpus have a very strong positive reaction. against the RCA lectins in the metestrous phase (Figure F). 40x2.5 magnification.
Description $=(-)$ : no reactivity, $(+++)$ : very strong reactivity.

\subsection{UAE-I Lectins}

UEA-I lectins indicate the presence of L-Fucose (LFuk) sugar residues in cells and / or tissues. Zhou et al.,[17] stated that UEA lectin reactivity is closely related to uterine endometrial preparation for embryo implantation. UEA lectins bind significantly to the Lfucous glycoconjugate. This is supported by Blackmore and Eisoldt [18] and Töpfer-Peterson [19] who state that L-fucous glycoconjugates are involved in adhesions between cells. The results of research conducted on the endometrium of Aceh cattle showed that there was a good activity of preparation and maintenance of the embryo implantation process due to the finding of an indicator in the form of UEA lectin reactivity which was very strong at various stages of the estrous cycle.

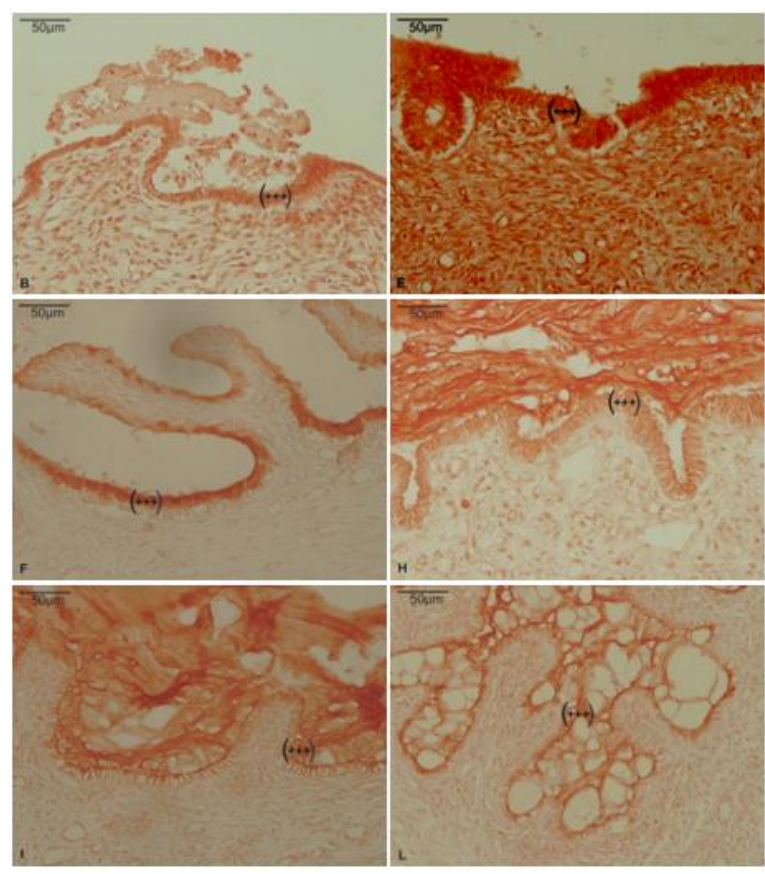

Figure 5. Overview of glycoconjugate reactivity in the endometrium of aceh cattle with UEA-I lectin histochemical staining. The mucosal epithelial lamina cells in the corpus reacted very strongly to UEA-I lectins in the proestrus phase (Figure B), mucosal epithelial lamina cells in the corpus (Figure E) and cervix (Figure F) had a very strong positive reaction to the UEA-I lectin in this phase. estrus, mucosal epithelial lamina cells in the corpus (Figure $\mathrm{H}$ ) and cervix (Figure I) have a very strong positive reaction to UEA-I lectins in the metestrous phase, and mucosal lamina epithelial cells in the cervix have a very strong positive reaction to UEA-I lectins in the diestrous phase . 40x2.5 magnification. Description $=(+++)$ : very strong reactivity.

In the uterine cervix, UEA lectin reactivity was found which was quite strong in the proestrus stage, and the 
reactivity was very strong in the estrous, metestrous and diestrous phases. UEA reactivity in the metestrous and diestrous phases in the uterine cervix is thought to be strongly related to the closure of the cervical uterine lumen to prevent infection with microorganisms during pregnancy.

Different results can be seen in the proestrus phase in the form of a strong reactivity of the UEA lectins, and in the estrous phase the reactivity becomes very strong. This condition suggests that the high success of the artificial insemination process in Aceh cattle is probably due to the closure of the uterine cervical lumen during the estrous phase.

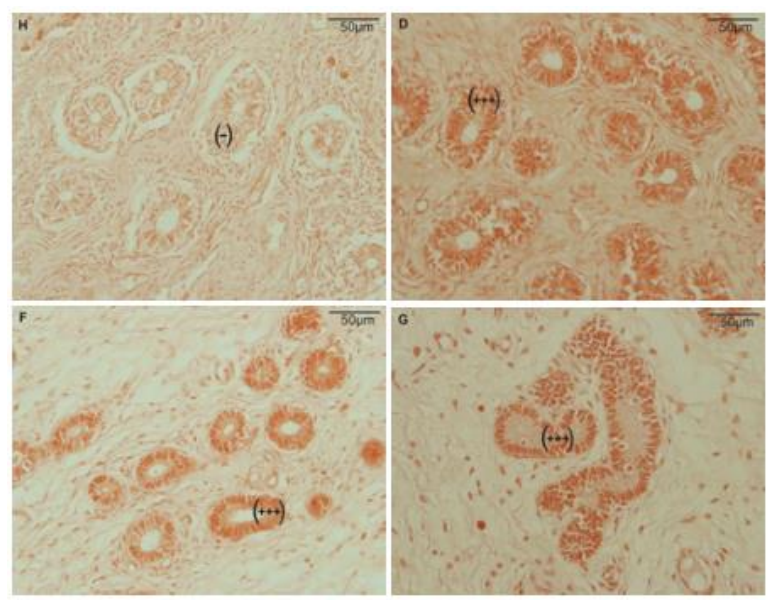

Figure 6 Overview of glycoconjugate reactivity in the uterine glands of aceh cattle with UEA-I lectin histochemical staining. Uterine glandular cells in the corpus react very strongly to UEA-I lectins in the estrous phase (Figure D), uterine glandular cells in the corpus react very strongly to UEA-I lectins in the metestrous phase (Figure F), and uterine glandular cells in the Cornua had a very strong positive reaction to the UEA-I lectin in the diestrous phase (Figure G). 40x2.5 magnification. Description = (-): no reactivity, $(+++)$ : very strong reactivity.

\section{CONCLUSION}

The residual glycoconjugate D-galactose, L-fucose, D-mannose / D-glucose, and N-acetyl-D-glucosamine are neutral glycoconjugates that can be identified in the endometrium of aceh cattle during the estrous cycle.

Considering that glycoconjugates have an important role in the reproductive process, this research should be continued to be able to identify other types of glycoconjugates that bind to neutral and acid carbohydrate groups in the endometrium of Aceh cattle. In order to obtain more perfect data and information sources, it is advisable to carry out further research with more complete types of lectins and a greater number of observations.

\section{AUTHORS' CONTRIBUTIONS}

All authors read and approved the final manuscript.

\section{ACKNOWLEDGMENTS}

Thanks are conveyed to the Chancellor of Syiah Kuala University, Dean of the Faculty of Veterinary Medicine, Syiah Kuala University, Director of the Indonesia Managing Higher Education for Relevance and Efficiency (HE-IU I-MHERE) University of Syiah Kuala who has supported this research.

\section{REFERENCES}

[1] B. Pancaputra, Daging Sapi Aceh Termahal di Dunia, Bibit 1(1) (2008) 31-33.

[2] [USDA] United States Department of Agriculture, Surveillance and Data Systems for USDA/APHIS/VS, 2010.

[3] H. Muntasib, B. Masy'ud, Dasar-Dasar Konservasi, Edisi Pertama, Pusat Penerbitan Universitas Terbuka. Jakarta, 2003.

[4] Y. Kimura, N. Manabe, S. Nishihara, H. Matsushita, C. Tajima, S. Wada, H. Miyamoto, Up-regulation of the $\alpha 2,6$-sialyltransferase messenger ribonucleic acid increases glycoconjugates containing $\alpha 2,6$ linked sialic acid residues in granulose cells during follicular atresia of porcine ovaries, Biol. Reprod 60 (1999) 1475-1482.

[5] J. Priedkalns, Sistem Reproduksi Betina. Dalam: Buku Teks Histologi Veteriner II. Brown D, Edisi Ketiga, UI Press, Jakarta, 1989, 486-528.

[6] D. Chateu, N. Boehm, Regulation of differentiation and keratin 10 expression by all-trans retinoic acid during estrous cycle in the rat vaginal ephitelium, Cell Tissue Res. 284 (3) (1995) 373-381.

[7] P.L. Cooke, D.L. Buchanan, D.B. Lubchan, G.R. Cuncha, Mechanism of estrogen action: lessons from the estrogen receptor- $\alpha$ knockout mouse, Biol. Reprod. (59) (1995) 470-475.

[8] E. Rahmi, Perkembangan kelenjar lambung monyet ekor panjang (Macaca fascicularis) pada periode pre-natal dan post-natal, Sekolah Pascasarjana, Institut Pertanian Bogor, Bogor, 2005.

[9] Hamny, Studi morfologi organ reproduksi kancil (Tragulus javanicus) dengan tinjauan khusus pada ovarium, perkembangan folikel dan pematangan oosit in vitro, Sekolah Pascasarjana, Institut Pertanian Bogor. Bogor, 2006.

[10] L.G. Luna, Manual of histologic staining methods af the armed forces institute of pathology. $3^{\text {rd }}$ Edition, 
The Blakiston Division McGraw-Hill Book Company, New York, 1968.

[11] J.A, Kiernan, Histological \& Histochemical Methods: Theory \& Practice. $2^{\text {nd }}$ Edition, Pergamon Press, England, 1990.

[12] M.C. Wulster-Radcliffe, R.C. Seals, G.S. Lewis Progesterone increases susceptibility of gilts to uterine infections after intrauterine inoculation with infectious bacteria, J. Anim. Sci. 81 (2003) 12421252.

[13] R.A. Hock, M.D. Hollenberg, Characterization of the receptor for epidermal growth factor-urgastrone in human placenta membranes, J. Biol Chem. 255 (1980) 10731-10736.

[14] L. Munson, J.J. Kao, Schlafer, Characterization of glycoconjugates in the bovine endometrium and chorion by lectin histochemestry, J. Reprod. Fert. 87 (1989) 509-517.
[15] B. Horvat, Galactose-binding lectins as markers of pregnancy-related glycoproteins, Histochem. 99: (1993) 95-101.

[16] B. Nixon, Q. Lu, M.J. Wassler, C.I. Foote, M.A. Ensslin, B.D., Shur, Galactosyltransferase function during mammalian fertilization, Cells Tissues Organs 68 (2001) 46-57

[17] Z.X. Zhou, Z.P. Deng, J.L. Chen, Characterization of glycoconjugates in the endometrium of the miniature pig during different reproductive periods, J. Reprod. Fert. 100 (1994) 417-423.

[18] P.F. Blackmore, S. Eisoldt, The noeglycoprotein mannose-bovine serum albumin, but not progesterone, activates t-type calcium channels in human spermatozoa, Mol. Hum. Repro. 5 (1999) 498-506.

[19] E. Tőpfer-Peterson, Carbohydrate-based interactions on the route of a spermatozoon to fertilization, Hum. Reprod. Update 5 (1999) 314-329 